\title{
AN ANALYSIS OF TEACHERS' CREATIVITY IN MEDIA-BASED LEARNING GRADE X AT SMK PENCAWAN MEDAN
}

\author{
${ }^{1}$ Epria Primsa Meliala, ${ }^{1,2}$ Pebri Wati Romatua Purba, ${ }^{1}$ Likawati Doloksaribu, ${ }^{1}$ Lavia \\ Panjaitan, ${ }^{1}$ Natalia Widya Pasca Tarigan \\ ${ }^{1}$ English Language Education, University of Prima Indonesia, Medan Indonesia \\ ${ }^{2}$ Corresponding Author Email: dolosaribu@gmail
}

\begin{abstract}
This study aims to describe the creativity of English teachers when SMK Pencawan Medan grade $\mathrm{X}$ use learning media. This research is descriptive. The data is obtained through interviews. The data analysis followed some steps, namely collecting data, reducing, display data, data verification and create reports. The results showed that teachers employed the various teachinglearning media in ELT classes. English teachers used various media to make it easier for students to learn and understand the teaching materials. The media include audio, visual, and audio visual. The most media used in the ELT classes were audio and visual. A small part of the media is produced through internet sources. However, the teacher's implementation method is not optimal. This can be seen from the imperfect application of the PowerPoint medium when the teacher uses the power point medium. Not every day teachers use the learning medium to achieve their learning goals. Based on the conclusion above, the researchers give suggestion to the teachers should always looking for creative new things and create active, innovative, and fun learning, and also motivate students to seriously participate in learning even though they study through online.
\end{abstract}

Keywords : Creativity, Learning media 


\section{CHAPTER I}

\section{INTRODUCTION}

Kunaryo (2013) argued that: "Education in a broad sense contains meaning how to educate, guide, teach and train. School is education that is held outside of the teaching and learning school which does not have to be done tiered continually". Education is also the key of progress and developments quality, because through education, human can realize all the potential well as individuals or as citizens. In order to realize potential self into multiple competencies must go through the educational process implemented in learning process. According to Herbart education is the formation of students to the wanted educators who are termed Education. According to Dewantara (1961) argues that education is all the efforts of parents to children with the aim of supporting the progress of their life. From the theory above, we can conclude that education is the key to all his potential well as individual and as citizens and education is very important to humanity.

Until now, education activists are always trying to develop good and effective learning methods and media to help teachers in convey his knowledge to his students. In teaching the teacher must able to present the best possible lesson to achieve the desired goals by using good and appropriate media.

Creativity is all activities that bring about innovative, useful, and understandable results. Creativity teachers are people who master science (experts), and have autonomy (learning) in the classroom. Creative teachers set goals, intentions, build basic skills, encourage the acquisition of certain knowledge, stimulate curiosity and exploration, build motivation, encourage confidence and dare, organize learning using various techniques, and build a conducive environment on the growth of creativity Al-Girl (2007). Creativity can be defined as new useful results, such as combining unrelated things into new things, or borrowing ideas and insights from a field and adapt them to different environments (Amabile, 1996; Shin \& Zhoun, 2007).

In teaching learning process also uses media to make the process effective and interesting. This part introduces the definition of teaching media, the functions of teaching media, and the type of teaching media. Generally, teaching media refers to all the tools that 
teachers can use to provide teaching materials to students in the teaching learning process to achieve certain learning goals.

According to Bakri (2011:3) media is variety of form of media, derived from the Latin Medius, which means "middle". In Bahasa language, means "between or interval". The meaning of media that aims to convey information (massage) between message sender and the receiver is based on Arsyad (2009:4). The teaching media is a kind of media with the purpose of massages or learning information. The media is means of expressing massage and information. According to Heinich (2013:17-18), the medium acts as an intermediary to pass information between sender and the receiver. When the media brings instructional messages or information that contain learning purposes, it can be called as teaching media. According to the above definition, we can draw conclusions: the media involves techniques and method in the teaching process. In other word, media is all auxiliary means/ tools that teachers and learners can use to achieve certain educational goals.

Based on observations of researchers with one of the teachers of SMK Pencawan Medan, there is a phenomenon that is observed as a problem of the lack of creativity of the teacher in using learning media, this can be seen from the learning process made by the teacher in the classroom. Teacher only use visual media because it is easy, teachers do not take advantage of existing media in school.

Based on the problems as in the background above, the researchers limit focus of this paper that "AN ANALYSIS OF TEACHERS CREATIVITY IN MEDIA-BASED LEARNING GRADE X AT SMK PENCAWAN MEDAN', So that the researchers be able to find how the teacher's creativity in using media and what the advantages and disadvantages in using media in learning process. 


\section{CHAPTER II RESEARCH METHOD}

\section{Research Design}

The study would be conducted by used Qualitative Research Method. Descriptive Design is used to describe the answers to existing questions, such as the content, object, time, place and method related to the research question. Researchers would be observed the topics in the environment and analyzed the data in detail to come up which important recommendation.

\section{Subject of Research}

In this study, teachers used as the data sources. As sources of data collection, the subject of the study was the teachers in SMK Pencawan Medan which is located on Jln Bunga Ncole which consists of 6 teachers. The subjects were interviewed by researchers to obtain the data.

\section{Instruments of Collecting Data}

Research instruments consist of interview. Researchers interviewed teachers and record them to collect the data. After interviewed the researchers would get the results of teacher's creativity in media-based learning.

\section{The Technique of Analysis Data}

In this study, the qualitative method used to analyzed data. The data analysis would be obtained from interview. Researchers analyzed teachers creativity in using media. To analyzed the data, researchers used a model Miles and Hubermen (1990) that is flow model analysis. In this analysis activity is perform the stages of analyzing data as follows:

1. Collecting data

2. Reducing

3. Display data

4. Data verification / conclusion 


\section{CHAPTER III \\ RESEARCH FINDINGS AND DISCUSSION}

\section{Research Findings and discussion}

Based on the results of research on English Teachers Creativity in Media-Learning Grade X At SMK Pencawan Medan, there are two aspects would be describe by researchers.

\section{Teachers Creativity in Using Media}

According to the teachers that has been interviewed by the researchers, the creativity of teachers at SMK Pencawan Medan in general the first to used google classroom which aims to simplify, distribute, and assess assignments without having to meet face to face so that teachers are lighter in implementing the learning system. The second to used PowerPoint makes the introduced materials attractive and easy for students to understand. The third, the teacher also took learning materials in the form of videos from You-tube because students were also more interested in the learning system in the form of videos because it was more fun and attracted students' attention to learn. And the last one is Zoom meeting, which is an application that provides remote conferencing services by combining video conferencing, online meetings, and currently the learning system from zoom meetings is indeed more attractive to teachers, especially in this pandemic, because this zoom meeting application can face-to-face with students from online.

\section{Advantage and Disavantage in Using Media}

\subsection{Advantages}

According to Sumarti and Pernama, function media is useful in, for example, process teaching.

1. An effective teaching method.

2. All components of the teaching plot.

3. Despise basic concrete and abstract concepts to reduce the persistence of oral expression.

4. Motivate students.

5. Expand teaching quality.

After the researchers conducted interview with the teachers of SMK Pencawan Medan, there are several advantages that has been mentioned by them. They are : 
1. Students do not get bored easily

2. Teachers teach more efficiently because they don't need to explain too much.

3. The material can be read anywhere and anytime, not bound by time and place.

\subsection{Disadvantages}

In general, there are several disadvantages of the media learning such as:

1. The student ability to listen the speed of recorded sound is usually not same between one student and another student. For examples there are student who quickly catch material from the recorded sound and there are also students who are weak in capturing the material.

2. To emphasizing mastery of the material rather than development process and still seeing audio-visual material as a teacher aids in the learning process. Some learning media are relatively expensive. So not all schools can't afford to provide examples projectors.

According to the teachers that has been interviewed by the researchers there were some disavantages. They are:

1. Teachers must be able to use or know about technology.

2. Another drawback, schools must provide more funds.

3. Requires a long manufacturing time

4. Visual media is not followed by audio, so that it requires an explanation from the teacher about the learning material

5. Requires good materials and media design and practical, in order visual media can last a long time, so the manufacturing process is quite complicated if there is an error in the media, it is difficult to fix Can so dismantle and start all over again the media. 


\section{CONCLUSION}

Based on the research the data analysis, that the creativity of teachers at SMK Pencawan Medan can be applied in 2 point based on the problems. The first point is that teachers creativity to teach used google classroom which aims to simplify, distribute, and assess assignments without having to meet face to face so that teachers are lighter in implementing the learning system. The used PowerPoint makes the introduced materials attractive and easy for students to understand. The teacher also took learning materials in the form of videos from You-tube because students were also more interested in the learning system in the form of videos because it was more fun and attracted students' attention to learn. And used Zoom meeting, which is an application that provides remote conferencing services by combining video conferencing, online meetings, and currently the learning system from zoom meetings is indeed more attractive to teachers, especially in this pandemic, because this zoom meeting application can face-to-face with students from online. The second point is advantages and disadvantages in used media. Advantages there are Students do not get bored easily, teachers teach more efficiently because they do not need to explain too much, the material can be read anywhere and anytime, not bound by time and place. And disadvantages in used media there are teachers must be able to use technology, the school must provide more funds, the manufacturing process is quite complicated if there are errors in the media it is difficult to fix them. It can be so unpacking and starting over the media again the media. 


\section{REFERENCE}

Creswell, J. W. (n.d.). Research Design Qualitative, Quantitative, And Mixed Method Approaches. SAGE.

Dalia Lapeniene, J. B. (2010). Teachers' creativity in the domain of prefossional activity. Analysis of individual factors. Lituanistika.

Dedy Royadi, N. S. (2019). Effectivness Management of Qualitative Research in Writing Scentific Papers. ATM, 3.

Fitriah. (2018). THE ROLE OF TECHNOLOGY IN TEACHERS' CREATIVITY DEVELOPMENT I ENGLISH TEACHING PRACTICES. TEFLIN.

G.Gunawan, A. H. (2017). VIRTUAL LABORATORY OF ELECTRICITY CONCEPT TO IMPROVE PROSPECTIVE PHYSICS TEACHERS CREATIVITY. JURANL PENDIDIKAN FISIKA INDONESIA.

HUSKHO, U. (2017). THE INFLUENCE OF TEACHERS CREATIVITY IN CLASSROOM MANAGEMENT AND UTILIZATION LEARNING MEDIA TOWARD STUDENTS LEARNING OUTCOME IN SOCIAL SCIENCE SUBJECTS GRADE VII AT MTsM MALANG III GONDANGLEGI. CENTRAL LIBRARY OF MAULANA MALIK IBRAHIM STATE ISLAMIC UNIVERSITY OF MALANG, 157.

Indri Dwi Isnaini, M. P. (2019). Teacher's Creativity in the Development of Learning Media Fun Book in Kindergarten. Proceeding of the International Conference on learning Innovation.

Joanna Black, K. B. (2011). Creativity in Digital Art Education Teaching Practices. Art Education.

Munir, F. (2016). The Effectivness of Teaching Vocabularynby using Cartoon Film toward Vocabulary Mastery of EFL Students. Journal of English Teaching and Linguistic(JELTL), 11.

Osly Usman, R. S. (n.d.). The Influence Of Learning Media, Teaching Methods, E-learning and Teacher's Creativity Of Learning Interest. p. 6.

Panut Setiono, I. R. (2017). Kreativitas Guru Dalam Menggunakan Media Pembelajaran Di Kelas V Sekolah Dasar. Jurnal Gentala Pendidikan Dasar, 219. 
Prabakti Endramawan, Y. T. (2016). Peningkatan Hasil Belajar Siswa Berbasis Aktivitas Pada Materi Arus Tegangan dan Tahanan Listrik Di SMK NEGERI 1 WONOSARI. JUPITER (Jurnal Pendidikan Teknik Elektro), 47.

Sahudra, T. M. (2019). Teacher Creativity Efforts In Providing Learning Media At State Senior High Scholol "Youth Vocational" In Aceh Tamiang". IJLRES - Internasional Journal on Language, Research and Education Studies.

Tafonao, T. (2018). Peranan Media Pembelajaran Dalam Meningkatkan Minat Belajar Siswa. Jurnal Komunikasi Pendidikan, 2.

W.Giessen, H. (n.d.). The Medium, The Content, And The Performance: And Overview On Media Based Learning. p. 6. 